\title{
Central Precocious Puberty as a Complication of Congenital Adrenal Hyperplasia in a Boy: Case Report
}

\author{
FARZANA SHARMIN ${ }^{1}$, SURAIYA BEGUM ${ }^{2}$, ISMAT JAHAN ${ }^{1}$ TAWHID ALAM ${ }^{1}$, DHIRAJ CHANDRA BISWAS ${ }^{1}$
}

\begin{abstract}
:
Precocious puberty has intense influence on physical and psychosocial well-being of affected children and raises a lot of concerns as well as uncertainties in family. Here, we report a case of Central precocious puberty (CPP)superimposed on peripheral precocious puberty (PPP) due to congenital adrenal hyperplasia(CAH).
\end{abstract}

\section{Introduction :}

Precocious puberty is defined by the development of secondary sexual characteristics before 8 years of age in girls and 9 years in boys. ${ }^{1}$ A Danish epidemiologic study estimated that incidence of precocious puberty was less than 5 per 10000 boys $^{2}$ and a study of Korean population estimated the prevalence of CPP to be 1.7 per 100000 boys. ${ }^{3}$ The prevalence of PPP in boys is not well documented. Data from two studies of Indian subcontinent reported that precocity is less observed in boys compared to girls and PPP was more common than CPP in boys $(55 \%$ vs $35 \%){ }^{4}$

Precocious puberty classifies into two major categories based on the etiology - Central precocious puberty (GnRH dependent) and Peripheral precocious puberty (GnRH independent).

Central precocious puberty also called true precocious puberty, is caused by early activation of hypothalamicpituitary-gonadal (HPG) axis, resulting in early but normal development, symmetric progression of secondary sexual characteristics, and increasing growth velocity. It is idiopathic in more than $80 \%$ cases and is more common in girls. Secondary causes of CPP include Central Nervous System (CNS) tumour (commonest tuber cinereum hamartoma), infection, congenital defect, radiation or injury. ${ }^{5-7}$ Peripheral precocious puberty, also called pseudo-precocious puberty does not involve the HPG axis and is caused by release of sex steroid from adrenal, gonad or exogenous source or ectopic gonadotropin production from germ cell tumour. Peripheral precocious produce

1. Phase B Resident, General Paediatrics, BSMMU, Dhaka

2. Professor, Department of paediatrics, BSMMU, Dhaka.

Correspondence: Dr. Farzana Sharmin, Phase B, Resident, General paediatrics, Block-C, $1^{\text {st }}$ floor, BSMMU. Cell no01681825433,E-mail: sharminfarzana348@gmail.com Received: $1 / 07 / 2020$ incomplete, atypically sequenced or rapid pubertal progression. ${ }^{8,9}$

Considerable limitations persist in optimally managing this condition as cultural and social issues, such as stigma and shame associated with early pubertal development responsible for not seeking early medical advice as well as less adherence to treatment.

\section{Case presentation:}

An 8year old boy, was brought by his parents due to their anxiety about the boy's continuing growth in phallic length along with erection since the age of one and half (1.5) year. There was also appearance of pubic hair at 2-3year of age and axillary hair after that. Parents also gave history of sudden height gain from $3^{\text {rd }}$ year of age. For last 6-7 months, he had developed adult body odour and acne. He had no history of headache, visual problems, behavioral changes or neurological deficits, any head trauma or surgery. Family history and perinatal history was unremarkable. He was treated with oral medroxyprogesterone and hydrocortisone since his $3^{\text {rd }}$ year of age by a registered physician and drug compliance was poor and was on irregular follow up.

Physical examinations revealed, weight was on $97^{\text {th }}$ centile, height was $143 \mathrm{~cm}$ above $97^{\text {th }}$ centile, height SD score (SDS) + 2.7, mid parental height $164.6 \mathrm{~cm}$, target height $156 \mathrm{~cm}$ to $173 \mathrm{~cm}$ and his predicted height lies above target height, BMI $18.8 \mathrm{Kg} / \mathrm{m} 2$ (on $90^{\text {th }}$ centile). His stretched penile length was $8 \mathrm{~cm}$, and testicular volume of $5 \mathrm{~mL}$ on the right and $6 \mathrm{~mL}$ on the left, pubic hair distribution matched with Tanner stage 4 and had sparse axillary hair (Tanner stage 2). There were no skin or bone lesions suggestive of McCune Albright syndrome. Systemic examinations were unremarkable. 


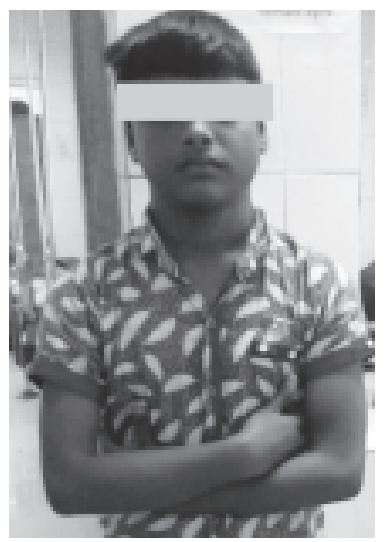

Fig.-1: Masculine appearance of this $8 y$ r old boy.

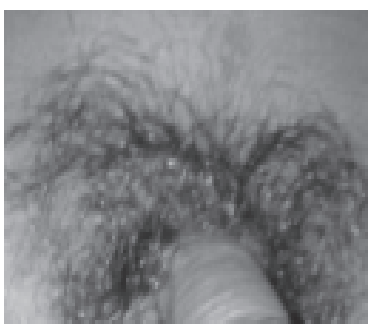

Fig.-2: External genitalia of this 8yr old boy.

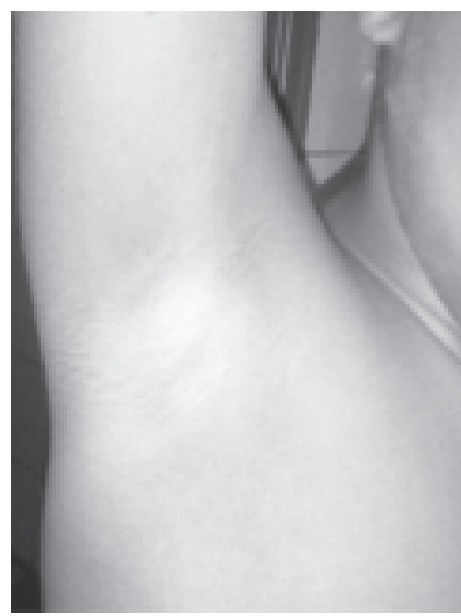

Fig.-3: Sparse axillary hair.

This 8 year old boy, had signs of puberty as evidenced by appearance of pubic hair and axillary hair, increased penile length and enlarged testicular volume, his laboratory evaluations were low cortisol, high ACTH and raised 17-hydoxy-progesterone and DHEA-S which suggested peripheral precocious puberty (PPP) due to congenital adrenal hyperplasia $(\mathrm{CAH})$. Rapid ACTH stimulation test confirmed diagnosis of $\mathrm{CAH}$. FSH, $\mathrm{LH}$ and free testosterone levels were in pubertal range and his bone age was also advanced. GnRH stimulation test was not done as his basal LH level was high which favoured CPP. Finally, his diagnosis was Central precocious puberty on peripheral precocious puberty due to congenital adrenal hyperplasia as his testicular volume was more than $4 \mathrm{~mL}$ and had high LH value. We advised oral hydrocortisone and $\mathrm{GnRH}$-analouge. The patient was on regular follow up and responded to treatment.

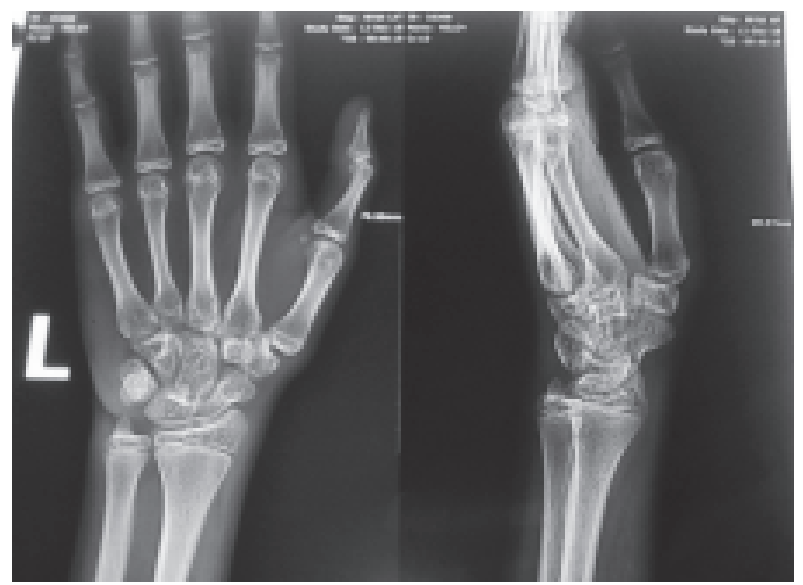

Fig.-4: X-ray of bone age of this 8yr old boy.

\section{Discussion:}

Puberty is a complex transitional phase in children generally comprising of growth acceleration and development of secondary sexual characteristics. Several genetic, environmental and nutritional factors play an important role in the onset and progression of puberty. ${ }^{10}$ Any boys with signs of puberty before nine years of age should be evaluated for precocious puberty. PPP in boys results from increased androgen production by the testes or adrenal glands. $\mathrm{CAH}$ is the most common cause of PPP in boys and CAH can present with $\mathrm{GnRH}$-dependent precocious pubertyrarely. Clinical observations suggest several hypotheses about the mechanism of CPP in $\mathrm{CAH}$ 1) the chronic elevated level of androgen precursors causing premature reactivation of the $\mathrm{GnRH}$ pulse generator of the hypothalamus 2) there is a direct correlation with advanced bone age 3 ) the decline in androgen levels after hydrocortisone treatment may cause the increase in gonadotropin secretion through a negative feedback. 1,11,13,14 Inspite of clinical and hormonal evidence of central precocious puberty ultimately an adrenal pathology was established in 2 different case reports. Their age of initial presentation was ( 2 year and 10 month respectively), our case presented at 1.5 year, but they presented to reporting authors at age of (6 year and $61 / 2$ year respectively) and 8 year in our case with features of CPP. Their initial presentation was like PPP and had increased penile length, pubic hair development but testicular volume was $<4 \mathrm{~mL} .{ }^{11,12} \mathrm{~A}$ case series containing three male children having CAH with Gonadotrophinreleasing hormone $(\mathrm{GnRH})$ dependent $\mathrm{CPP}$ was comparable to our case which was more florid in 
Table-I

Showing laboratory evaluations

\begin{tabular}{lll}
\hline Tests & Result & Normal values \\
\hline Serum Electrolytes & & \\
Serum Sodium & $141 \mathrm{mmol} / \mathrm{L}$ & $135-145 \mathrm{mmol} / \mathrm{L}$ \\
Serum Potassium & $4.1 \mathrm{mmol} / \mathrm{L}$ & $3.5-5.1 \mathrm{mmol} / \mathrm{L}$ \\
Serum Chloride & $102 \mathrm{mmol} / \mathrm{L}$ & $95-107 \mathrm{mmol} / \mathrm{L}$ \\
Serum TCO2 & $24 \mathrm{mmol} / \mathrm{L}$ & $22-30 \mathrm{mmol} / \mathrm{L}$ \\
Basal Cortisol & $63.3 \mathrm{nmol} / \mathrm{L}$ & $138-690 \mathrm{nmol} / \mathrm{L}$ \\
Basal ACTH & $743 \mathrm{pg} / \mathrm{mL}$ & Not detectable to $46 \mathrm{pg} / \mathrm{mL}$ \\
17-OH-Progesterone & $176 \mathrm{ng} / \mathrm{dL}$ & $3-90 \mathrm{ng} / \mathrm{dL}$ \\
Serum Testosterone & $300 \mathrm{ng} / \mathrm{dL}$ & $3-10 \mathrm{ng} / \mathrm{dL}$ \\
FSH & $1.25 \mathrm{IU} / \mathrm{L}$ & $0.26-3 \mathrm{IU} / \mathrm{L}$ \\
LH & $2.55 \mathrm{IU} / \mathrm{L}$ & $0.02-0.18 \mathrm{IU} / \mathrm{L}$ \\
\hline & & \multicolumn{1}{c}{ Rapid ACTH stimulation test } \\
\hline Name of Test & $0 \mathrm{hr}$ & After $60 \mathrm{~min}$ \\
Basal ACTH & $727 \mathrm{pg} / \mathrm{ml}$ (Normal range- Not detectable to $46 \mathrm{pg} / \mathrm{ml}$ ) & \\
Basal Cortisol & $96 \mathrm{nmol} / \mathrm{L}$ (Normal range:138-690nmol/L) & $88.5 \mathrm{nmol} / \mathrm{L}$ \\
DHEA-S & $329.5 \mu \mathrm{dL}$ (Normal range:13-83 $\mu \mathrm{gg} / \mathrm{dL})$ & $378 \mathrm{\mu g} / \mathrm{dL}$ \\
17-OH- Progesterone & $120 \mathrm{ng} / \mathrm{dL}$ (Normal range:3-90 ng/dl) & $190 \mathrm{ng} / \mathrm{dL}$ \\
X-ray for bone age & Corresponds to 13-14 yrs, advanced bone age & \\
USG of abdomen & Normal & \\
TSH & $4.59 \mathrm{mlU} / \mathrm{L}$ & $0.47-5.01 \mathrm{mlU} / \mathrm{L}$ \\
FT4 & $14.53 \mathrm{pmol} / \mathrm{L}$ & $9-19.05 \mathrm{pmol} / \mathrm{L}$ \\
MRI of pituitary gland & Normal pituitary gland & \\
\hline
\end{tabular}

presentation. ${ }^{15}$ Our patient was a simple virilizing (SV) variety of $\mathrm{CAH}$ as he presented with precocity without feature of salt wasting. Usually, patients with SV CAH, present with PPP, but may develop CPP due to premature activation of the hypothalamic-pituitarygonadal axis. Y Gani et al, observed that among 34 children of $\mathrm{CAH}, 10$ children with PPP due to $\mathrm{CAH}$, developed CPP during their follow up in a endocrine clinic of South Africa. ${ }^{16}$ Their CPP development was triggered by the chronic mild to moderate intermittent elevation of androgens in patients who are noncompliant with medication like our case. SV boys with advanced bone age of $>12$ years may have spontaneous CPP when treatment with hydrocortisone is initiated lately. Our patient's bone age was about 13-14 year and developed CPP due to advanced bone age. Here, the hydrocortisone suppresses the production of adrenal androgens and stimulates the release of gonadotrophins as inhibitory effects of adrenal androgens disappeared. ${ }^{16}$ It appears that proper glucocorticoid replacement to achieve adequate control of hyperandrogenemia during early life might prevent development of CPP in these patients. ${ }^{14}$ All the patients were on replacement therapy with hydrocortisone and $\mathrm{GnRH}$ analogue after evaluation and in our case, we followed the same footsteps. ${ }^{13,16}$

\section{Conclusion:}

CAH causing PPP, may turn into CPP in boys. Early identification and treatment with hydrocortisone and $\mathrm{GnRH}$ analogue should be started as soon as possible, because delay in management can lead to permanent short stature, sexual anxiety and sexual abuse.

\section{References:}

1. Meena D,Colaco MP, Choski CS. Isosexual precocity clinical and etiologic profile. Indian Paediatrics, 1993;30:617-23 
2. Teilmann G, Pedersen CB, Jensen TK, Skakkebaek NE, Juul A. Prevalence and incidence of precocious pubertal development in Denmark: an epidemiologic study based on national registries. Pediatrics. 2005;116:1323-8.

3. Kim SH, Huh K, Won S, Lee KW, Park MJ. A Significant Increase in the Incidence of Central Precocious Puberty among Korean Girls from 2004 to 2010. PLoS ONE. 2015;10:e0141844.

4. Tasnima A, Fauzia M, Nasreen I, Juben N, Kiswar A. Aetiology of precocious puberty in patients presenting to A Tertiary Care Hospital. Bang J Child Health 2017; 41: 143-46.

5. Lee PA, Kerrigan JR. Precocious puberty. In: Pescovitz $\mathrm{OH}$, Eugster EA (eds) Textbook of Pediatric Endocrinology. Philadelphia: Lippincott Williams \&Wilkins. 2004:316-30.

6. Kalantaridou SN, Chroussos GP. Clinical Review 148: Monogenic disorders of puberty. J clin Endocrinol Metab. 2002; 87:2481-94.

7. Kappy MS, Ganong CS. Advances in the treatment of precocious puberty. Advances in Pediatrics1994;41: 223-61.

8. Styne DM, Grumbach MM. Physiology and disorders of puberty. In: Melmed S, Polonsky KS, Larsen PR, Kronenberg $\mathrm{H}$, Williams RH, eds. Williams Textbook of Endocrinology. 13th ed. Philadelphia, Pa.: Elsevier; 2016: 1074-1218.

9. Kaplowitz P, Bloch C; Section on Endocrinology, American Academy of Pediatrics. Evaluation and referral of children with signs of early puberty. Pediatrics. 2016; 137: 1-6.
10. Wieland Kiess, Julia Hoppmann, Julia Gesing, Melanie Penke, Antje Korner, Jurgen Kratzch et al. Puberty - genes, environment and clinical issues. J Pediatr Endocrinol Metab. 2016;29:1229-31.

11. Pranab Kumar Sahana, Krisnasankar, Gopalsankar. Boy with central precocious puberty due to a peripheral cause.BMJ Case Rep 2016.doi:10.1136/bcr-2016-214554

12. Majumdar J ,Sharan A, MukhopadhyayS,Ghosh B, Sengupta S. Congenital Adrenal Hyperplasia- A Rare Cause of Central Precocious Puberty-A Case Report. Journal of Clinical and Diagnostic Research.2017; DOI: 10.7860/JCDR/2017/27330.10837.

13. Pescovitz $\mathrm{OH}$, Comite F, Cassorla F, et al. True precocious puberty complicating congenital adrenal hyperplasia: treatment with a luteinizing hormone-releasing hormone analog. Journal of Clinical Endocrinology and Metabolism 1984;58:857-61.

14. Soliman AT, AILamki M, AI Salmi I. Congenital adrenal hyperplasia complicated by central precocious puberty: linear growth during infancy and treatment with gonadotropin-releasing hormone analog. Metabolism 1997;6:513-17.

15. Veetil, V.M., Naseerali, M. Congenital adrenal hyperplasiapresenting as central precocious puberty. Int J Pediatr Endocrinol 2013, P118 (2013). https://doi.org/10.1186/ 1687-9856-2013-S1-P118.

16. $Y$ Ganie, $C$ Aldous,$Y$ Balakeishna,RWiersma.Congenital adrenal hyperplasia due to 21-hydroxylase deficiency in South Africa. South African Medical Journal 2018;108: 132-37. 